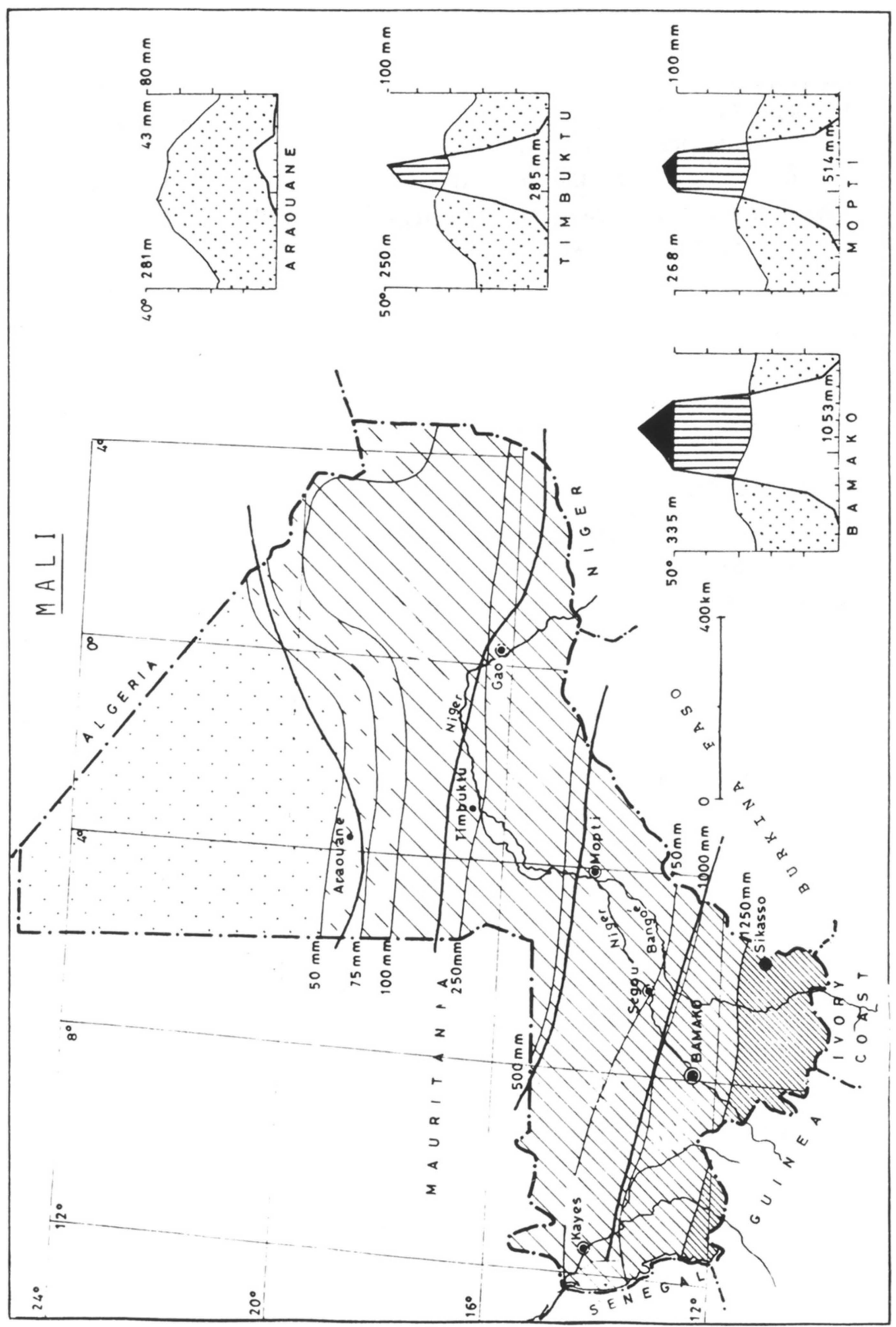




\section{AFRICA REVIEW}

\section{AN UP-TO-DATE GEOGRAPHICAL, HISTORICAL, POLITICAL AND ECONOMIC SUMMARY OF THE AFRICAN COUNTRIES}

Prepared by: F. Pauwels, P. Van Damme, D. Theeten, C. De Keyser, S. Hoste.

\section{MALI}

1. Official name: Republic of Mali.

République du Mali

2. Geography:

2.1. Situation: in West Africa, between $10 \mathrm{~N}$ and $25^{\circ} 30^{\prime} \mathrm{N}, 4 \mathrm{~W}$ and $18 \mathrm{~W}$.

2.2. Total area: $1240192 \mathrm{~km}^{2}$.

2.3. Natural regions: it is a country of low relief. The greater part of the surface is about $300 \mathrm{~m}$ above sealevel and is generally rather flat. Some 35000 $\mathrm{km}^{2}$ lie at altitudes above $500 \mathrm{~m}$, mostly around Adrar des Iforas. The drainage is centered on two large rivers: the Senegal in the west and the Niger in central Mali. Vegetation from north to south: desert, sahel vegetation, savanna steppe with Acacia spp., Euphorbia spp., baobab and borassus palm on moist places; sudan savanna and guinea savanna with Afzelia africana, Khaya senegalensis, Pterocarpus erinaceus, karité (Butyropermum parkii), néré (Parkia biglobosa), tamarind (Tamarindus indica) and baobab.

2.4. Climate: dry tropical to desertic from the south to the north. 
3. Population:

3.1. Total population:7.6 $\mathrm{ml}$ (1987),urban population: $20 \%$.

3.2. Population density: 6.1 per $\mathrm{km}^{2}$.

3.3. Population growth rate: $2.3 \%(1980-1985)$.

3.4. Capital: BAMAKO, 510000 inh. (1982).

3.5. Principal languages: French (official), bamanankan (bambara), fulfulde (peulh), songhay, dogoso (dogon), soninke, tamasheg, boomu (bobo), syènara (sénoufo), mamara (minianka), mandinka, bozo.

3.6. Religion: Muslim (65\%), traditional beliefs (30\%), Roman- Catholic (1\%), Protestant (1\%).

4. History:

The first written texts on the history of Mali deal with the kingdom of Ghana (1068). During the Middle Ages and later on, different reigns were established and disappeared. The leading peoples were consecutively the Songhay, the Tuareg, the Bambara, the Tekrour and the Fulani. The occupation and military actions of the French in the late 18th century resulted in the end of a period of internal fighting in which Bambara fought each other, Fulani and Bambara fought the Tekrour and the Malinke fought the Senoufo. In 1958, Mali acquired autonomy within the Franco-African Community. Together with Senegal the Federation of Mali became independent in 1960. Some months later, on 22 September 1960, the federation split up and Mali became fully independent.

5. Nature of political system:

Presidential Republic. The President is elected every six years. Legislative power is held by the National Assembly, consisting of 82 members, elected for a 3-year period. Mali is ruled by a single party, the UPDM (union démocratique du peuple malien). 


\section{Economy:}

GDP:agriculture:50\%, industry: $13 \%$, services: $37 \%$ (1985).

Employment: agriculture: 86\%, industry: 2\%, services: 13\% (1980).

\subsection{Mining:}

Although deposits of various minerals are present: bauxite, uranium and thorium near Kayes and Baloufabé, lithium near Bourgoni, copper, manganese platinum and phosphates in the region of Gao-Ansongo and the Adrar des Iforas, actual exploitation is limited to limestone, salt and marble.

\subsection{Agriculture:}

$1.5 \%$ of the total area is arable land or cultivated with permanent crops (1984). The $600 \mathrm{~m}$ isohyete is the northem limit for crop cultivation. The traditional food crops as sorghum, millet, cowpea, maize, rice and groundnuts, yams, sweet potatoes and cassava are cultivated on a subsistence level. Marketing of commercial crops as groundnuts, rice, cotton, fruits and vegetables are controlled by the government. The irregular regime of the rainfall hampers planning and is responsible for frequent crop failures.

\subsection{Livestock:}

$24 \%$ of the total area is permanent pasture (1984). Breeding is an important economic activity in Mali. In the north there are mostly camels which serve as beasts of burden. In the Sahel belt, Zebu cattle, sheep and goats predominate. An annual migration, north-south or vice versa, takes place according to the season.

\subsection{Forestry and woodland:}

$7 \%$ of the total area (1984). The sudan savanna is largely wooded, with species which increase in size and density from north to south. About $11000 \mathrm{~km}^{2}$ are forest reserve while the peasant farmers retain a number of useful trees (karité, néré, baobab, Acacia albida) in their crop fields.

\subsection{Fishery:}

Is an important activity and is rapidly developing especially on the Niger between Markala and the lake Débo. Annual catch is estimated at 90$100.000 \mathrm{t}$. 
6.6.Industry:

Mainly food processing industries.

6.7. Weights, measures and currency:

$\mathrm{kg}$, meter

1 Franc $($ Mali Fr $)=100$ centimes $=1$ franc de la Communauté financière africaine (CFA).

1 US $\$=280,625$ francs CFA.

7. Trade:

Total exports amount to $172 \mathrm{mln}$ US $\$$ (1985). Main export products are cotton, livestock, gum arabic, groundnuts, dried fish and rice.

Total imports amount to $363 \mathrm{mln}$ US \$ (1985). The most important trade partners are the EEC, the USSR, Ivory Coast, Senegal, Ghana, Czechoslovakia, China and Japan.

8. Miscellaneous:

World Bank classification: Mali belongs to the low-income economies with a GDP per capita of 150 US \$ (1985).

Membership of international organisations:

GATT, ILO, IMF, OAU, UN, WHO, African Development Bank, African Groundnut Council, Arab Bank for Economic Development in Africa (recipient), Economic Commission for Africa, Economic Community of West African States, French Monetary Area, Islamic Conference, Islamic Development Bank, West African Economic Community, WorldBank.

Mali is a signatory to the Lome Convention (EEC-ACP).

Embassy for Mali in Belgium: Molièrelaan 487

1060 Brussel

Tel. 02/345.75.89

Belgian Embassy for Mali: Route de la Corniche Est

P.O. Box 524

Dakar, Senegal 


\section{NIGERIA}

1. Official name: Federal Republic of Nigeria

2. Geography:

2.1. Situation: Nigeria lies on the eastern end of the coast of West Africa, near the Gulf of Guinea between $4^{\circ} 20^{\prime} \mathrm{N}$ and $14 \mathrm{~N}, 3 \mathrm{E}$ and $15 \mathrm{E}$.

2.2. Total area: $923773 \mathrm{~km}^{2}$.

2.3. Natural regions: Nigeria is essentially a low lying country, with about $80 \%$ of its area below $600 \mathrm{~m}$, and only $5 \%$ over $900 \mathrm{~m}$. Areas of high land are found in the center of the country (plateaux) whilst the north is characterized by plains, the south consists of low lying coastal landscapes with swamps, lagoons and mangroves.

2.4. Climate: because of Nigeria's inter-tropical situation, temperatures are high (generally over $20^{\circ} \mathrm{C}$ ). The annual rainfall decreases towards the north. This results in a Southern Forest Zone (tropical: wet and warm), a Middle Belt (savannas) and the Northern Sudan Zone (dry and warm), which has a rainy season during 4 to 6 months, followed by a long dry season.

\section{Population:}

3.1. Total population: $116.2 \mathrm{mln}$ (1986), urban population: $30 \%$.

3.2. Population density: 106 per $\mathrm{km}^{2}$.

3.3. Population growth rate: $2.5-3.1 \%$ (1986); U.N. $3.5 \%$

3.4. Capital: LAGOS, $6 \mathrm{mln}$ inh. (1985).

3.5. Principal languages: Edo, Efik, English (official), Fulfulde, Haussa, Ibo, Igola, Izon, Kanuri, Nupe, Tiv.

3.6. Religion: $44 \%$ Islam, $28 \%$ Christian, traditional religions. 
$N|G E R| A$

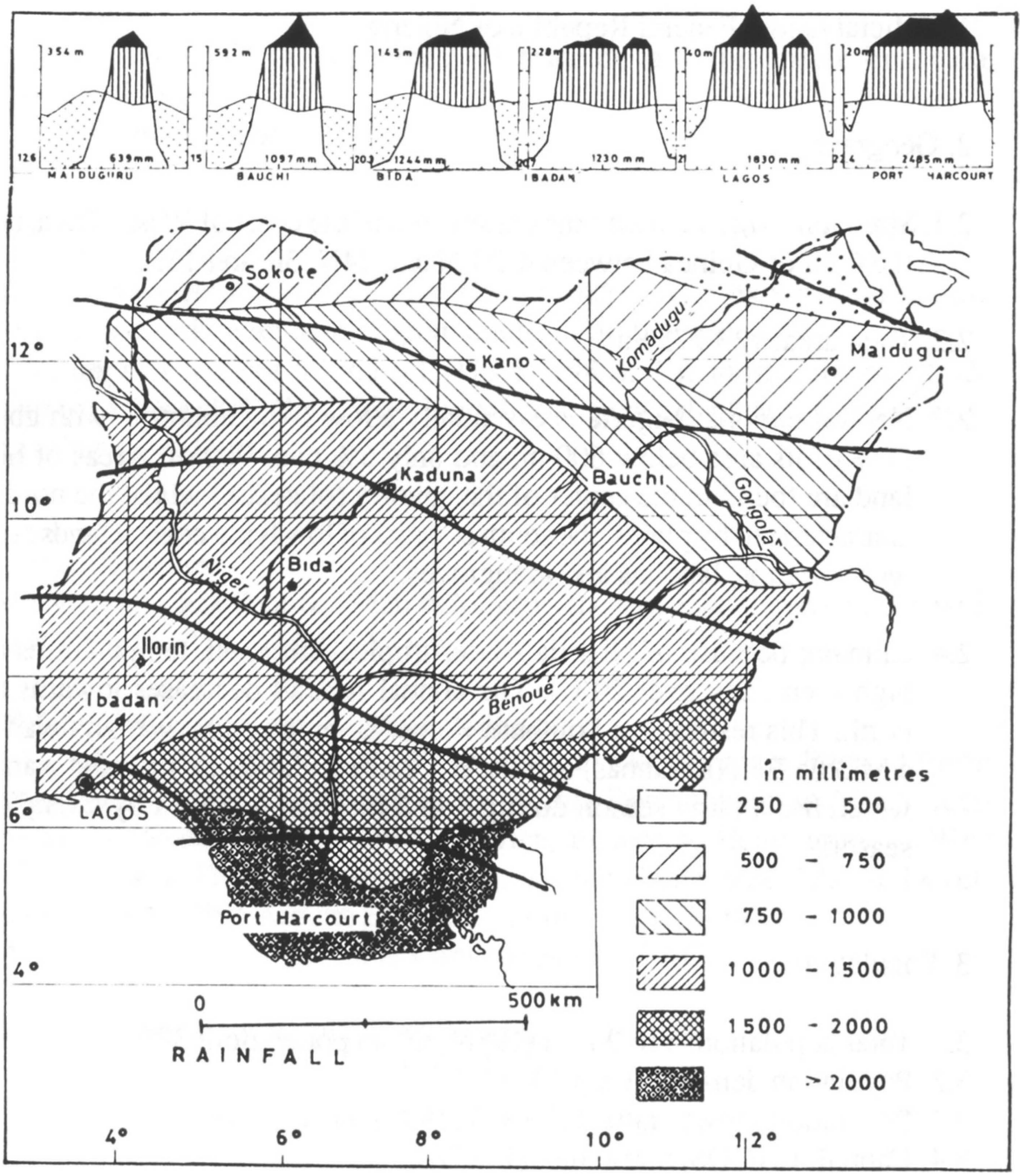




\section{History:}

Nigerian history starts more than thousand years ago with the foundation of different kingdoms. The Haussa city states in the North, the kingdoms of Oyo (Yoruba), Ibo and Benin in the South developed into well organized communities. They had contacts with the Islamic world through northern Africa, and also from the 15th century onwards with the Portuguese with whom they traded goods and humans. Slavery had a disintegrating effect upon traditional life and politics. In the end the might of the existing kingdoms was reduced by intermal warfare and by the "indirect rule" policy of the British who had started to colonize the country in the early 19th century. On the first of January 1914 the Colony and Protectorate was founded. Nigeria became independent on the first of October 1960. Internal disagreements between the different ethnic groups led eventually to a civil war when Eastem Nigeria proclaimed itselfs independent and formed the Republic of Biafra. After two and a half years of fighting and famine, the Biafran army surrendered in 1970.

\section{Nature of political system:}

After 13 years of military governing, democratic elections were held in the summer of 1979 which resulted in the election of a new civil president, Shagari, a Haussa, who got into office on the 1st October 1979. Several political parties are represented in both parliaments, but difficulties arise frequently because the major parties coincide with the major tribes: Yoruba, Haussa and Ibo. Each of the 19 states has its own parliament and governor. In December 1983, a military putsch replaced the democracy by a military government, and since then several coups have followed. The present military ruler is General Babangida. He promised presidential elections by the end of 1992, effectively ending military rule.

\section{Economy:}

GDP: agriculture: $36 \%$, industry: $32 \%$, services: $32 \%$ (1985). Employment: agriculture: $68 \%$, industry: $12 \%$, services: $20 \%$ (1980). 


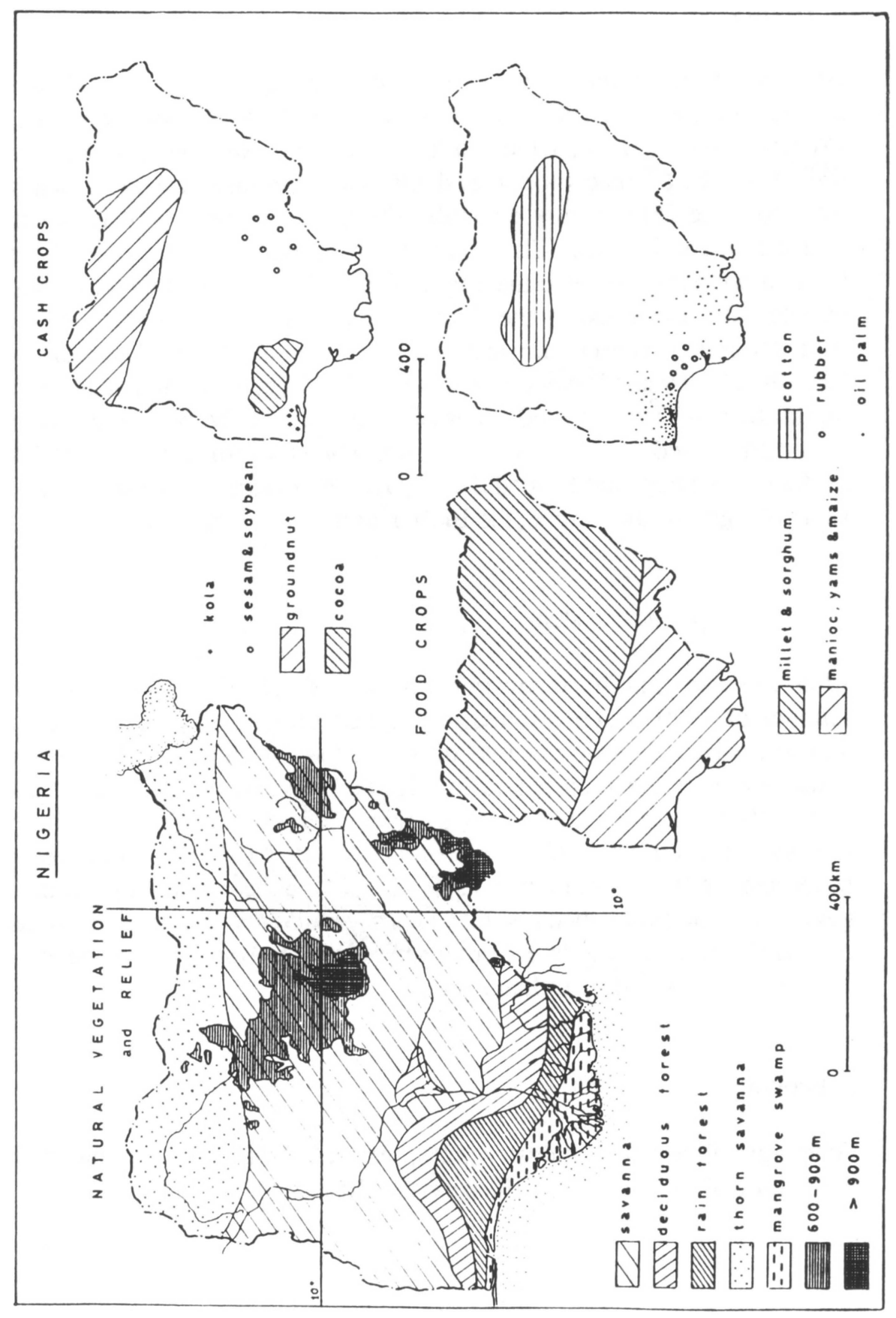




\subsection{Mining:}

Nigeria is the first oil-producer of Africa and ranks among the world's top producers. The production capacity is estimated at $2.4 \mathrm{mln} \mathrm{b} / \mathrm{d}$, but production is lower because of OPEC agreements (1.3 mln b/d in mid-1984). Nigerian oil is light and almost sulphur free. Furthermore, the country has important reserves of coal, natural gas and tin and it is the world's most important producer of columbite.

\subsection{Agriculture:}

$33.5 \%$ of the total area is arable land or cultivated with permanent crops (1984). Nigeria is the third most important producer of cocoa although bad weather and low prices have reduced production rates. These conditions affected the production of groundnuts and cottonseed in the same way. Other important products are: rubber, rice, sorghum, sesame, maize, cassava, yam, millet and cowpea. Secondary products are coffee, tobacco, gum arabic and copra.

\subsection{Livestock:}

$23 \%$ of the total area is permanent pasture (1984). Cattle raising is concentrated in the north because of the absence of tsétsé- flies. Total heads of cattle: $12 \mathrm{mln}$. Sheep $(11-12 \mathrm{mln})$, goats $(24-25 \mathrm{mln})$ and poultry $(130 \mathrm{mln})$ can be found throughout the country. Because the muslims in the north do not eat pork, pigs (1-1.2 mln) are concentrated in the south.

\subsection{Forestry and woodland:}

$16.5 \%$ of the total area (1984). Large forests are found in the southern forest zone. Timber and firewood are obtained both from the forest reserves as well as from the open tree forest areas. The more valuable species include mahoganies (Khaya ivorensis and Khaya anthotheca), African walnut (Lovoa michiloides), iroko (Chlorophora excelsa), sapele wood (Entandrophragma cylindricum), wawa (Triplochiton scleroxylon), afara (Terminalia superba) and opepe (Sarcocephalus diderrichii).

\subsection{Fishery:}

Total catches amount to $480-500000$ t/year of which $40 \%$ from the inland and $60 \%$ from the Atlantic waters. 


\subsection{Industry:}

Fast developing and varied industry. Numerous small family enterprises involved in the transformation of agricultural products (rubber factories, abattoirs, tanneries, oilmills). Refineries with a total capacity of $500000 \mathrm{~b} /$ day (production of motor oils, gasoline, kerosine). A large steel plant with a production capacity of $5.2 \mathrm{mln}$ t/year.

6.7. Weights, measures and currency:

$\mathrm{kg}$, meter

1 Naira $(\mathrm{N})=100$ kobo

1 US $\$=0.2496 \mathrm{~N}(1987)$

7. Trade:

Total exports amount to $12567 \mathrm{mln}$ US \$ (1985), mostly oil. Main clients are the EEC, the USA and Japan.

Total imports amount to 8877 min US \$ (1985) of which $21 \%$ food and $35 \%$ machinery and transport equipment. Main suppliers are the EEC, the USA and Japan.

8. Miscellaneous:

World bank classification: Nigeria belongs to the middle-income economies with a GDP per capita of 800 US \$ (1985).

Membership of international organizations:

GATT, ILO, IMF, OAU, OPEC, UN, WHO, African Development Bank, African Groundnut Council, Arab Bank for Economic Development in Africa (recipient status), Economic Commission for Africa, Economic Community of West African States, Intemational Cocoa Organization, Commonwealth, World Bank.

Nigeria is a signatory to the Lome Convention (EEC-ACP).

Embassy of Nigeria in Belgium: Tervurenlaan 288

1150 Brussel

Tel. 02/762.25.00 
Belgian Embassy in Nigeria: 1 A Bank Road

Ikoyi

P.O. Box 149

Lagos, Nigeria 